\title{
Applying the Delphi and fuzzy DEMATEL methods for identification and prioritization of the variables affecting Iranian citrus exports to Russia
}

\author{
Seyyed Mehdi Hosseini ${ }^{1} \cdot$ Yazdan Soltanpour $^{1} \cdot$ Mohammad Mahdi Paydar $^{1}$ (i) \\ Accepted: 31 December 2021 / Published online: 13 January 2022 \\ (C) The Author(s), under exclusive licence to Springer-Verlag GmbH Germany, part of Springer Nature 2022
}

\begin{abstract}
Foreign trade is one of the important components in economic development and a source of foreign exchange earnings. In Iran, the government desires to develop foreign trade with a focus on non-oil exports. One of the substantial non-oil products is agricultural products. Iran is one of the top ten countries in the world in terms of producing agricultural products, especially citrus, but it does not have suitable conditions in terms of exports. Mazandaran province is a considerable source of citrus production in Iran, and the main produced citrus in the province is exported to Russia. Worth bearing in mind that although the production rate of citrus in the province is very well, the amount of export is not very appropriate. Therefore, the government struggles to adopt an appropriate approach to improve the conditions and taking the right approach is not possible without identifying the variables affecting exports. In this regard, in this study, first, the variables affecting citrus exports regarding the case are determined using literature review and the most related those to the case study are selected using the Delphi method. Then, the identified variables are ranked using the fuzzy DEMATEL method. Focusing on the results, it can be observed that "exchange rate fluctuation" and "marketing" have the most and the least impact on the development of citrus exports from the province to Russia, respectively. Moreover, to better analyze the gained results, the determined variables are divided into two main categories based on stages of trade, and each category's variables are discussed in detail.
\end{abstract}

Keywords Foreign trade C Citrus exports · Delphi method · Fuzzy DEMATEL

\section{Introduction}

One of the most important goals of any country is to develop and improve its economic conditions. Improving and stabilizing economic conditions guarantees the life of each country and has a significant impact on the quality of life for people of that society (Goldstein and Khan 1985; Genç et al. 2020). One of the best ways to achieve this

Mohammad Mahdi Paydar

paydar@nit.ac.ir

Seyyed Mehdi Hosseini

sm.hosseini33@yahoo.com

Yazdan Soltanpour

yazdan.soltanpour@gmail.com

1 Department of Industrial Engineering, Babol Noshirvani University of Technology, Babol, Iran target is utilizing foreign trade. Foreign trade grows the gross domestic product (GDP) and has positive consequences for a country's economy and development (Nijssen and Douglas 2004). In trade, an integrated platform is provided for countries to achieve significant economic gains through various exchanges. Therefore, the future of countries is rooted in foreign trade (Temiz Dinç et al. 2017). Trade does not make sense internally and one-dimensionally; trade relations are very extensive, which saves any country from backwardness and stagnation. Foreign trade helps that more capital is easily imported into the country and kept up with the development of different technologies (Temiz Dinç et al. 2017). Every country may face problems such as lack of manpower, poor production, inability to use and launch new technologies and lack of sources of income. However, foreign trade can be the most efficient way to get out of these bottlenecks and bring dynamism and prosperity to society (Chen 2009). 
Iran's foreign trade flows are heavily dependent on Foreign Exchange Earnings (FEEs) from oil exports (Hosseini and Paydar 2021a). By looking at Iran's trade balance in different years, it can be observed that Iran is not in a good position in terms of foreign trade. Also, if oil revenues are excluded from the trade balance, the sum would be negative for all years. Therefore, all of these confirm that Iran relies on the export of oil products more than other items to earn foreign exchange. We know that oil is a non-renewable resource and it will run out, so it is not good for a country to rely only on the revenues gained from its sales. On the other hand, severe sanctions against Iran have reduced the sale of oil and its derivatives (Esfahani et al. 2013). As a result, adopting an appropriate strategy to deal with this problem is crucial. In other words, increasing non-oil exports is very important for Iran to provide the country's foreign exchange earnings and develop international interactions.

As mentioned earlier, most of the attention in Iran's foreign trade is on the export of petroleum and industrial products, and less attention is paid to the export of other products, especially agricultural products (Esnaashari et al. 2010), while Iran is in a privileged position in the agricultural sector due to the climatic conditions and fertile soil in terms of price and quality. Mazandaran province is one of the most important provinces in Iran in the production of agricultural products. Besides, citrus is the major part of the province's agricultural production. The amount of citrus production in Iran per year is about 5 million tons where about $2,700,000$ tons of that is produced in Mazandaran province. It means that about $54 \%$ of the country's citrus is produced in Mazandaran province and it indicates the significant position of Mazandaran province in the production of citrus in the country (Iranian Ministry of Agriculture Jihad 2020). Due to the reasonable price and high quality of citrus in the province, this product receives a high demand from other countries, especially Russia to be exported. According to statistics published by the Iranian Ministry of Agriculture Jihad, the amount of citrus production in Mazandaran province in 2020 was approximately equal to $2,700,000$ tons, while the amount of exported citrus was about 300 thousand tons, which shows about 11.2 percent of the produced citrus is exported and this amount is very low. Also, it shows that the government should pay considerable attention to this issue. Therefore, to solve this problem, the Iranian government seeks to adopt an appropriate strategy to take advantage of this sector to develop foreign trade and improve the country's economic situation. It is also clear that it is not possible to take the right approach without identifying the factors affecting the export of this product. Thus, in this study, we analyzed and studied the factors affecting citrus exports from Mazandaran province to Russia. In the present study, first, the variables affecting exports in Iran are extracted from the literature review. Then, the variables having the greatest impacts and relationships with citrus exports from Mazandaran province to Russia are identified using the Delphi method. Finally, by applying the fuzzy DEMATEL method, the selected variables are prioritized in order of effectiveness on export.

The rest of this study is managed as follows: In Sect. 2, papers related to the topic are reviewed and summarized. Section 3 describes the problem and the case study. Sections 4 and 5 present the methodologies used in the current research and the obtained results, respectively. Section 6 concludes the findings of the study.

\section{Research background}

Supply chain management of agricultural products has been approached through different perspectives. The majority focus is on the specific micro-conditions such as logistics (Chiadamrong and Kawtummachai 2008), supply and demand (Teimoury et al. 2013), and prices (Lee and Liu 2014). The context in which the agents of the supply chain interact is often assumed equal for all cases. A classical economic theory in a global market is supposed to apply to all commodity exchanges. However, this situation may not apply to all countries. The particular context that Iranian export agents find themselves in has clear dissimilarities with the common global trade. Compared to developed countries, Russia also finds itself with difficulties regarding international trade due to limitations imposed by other countries. A great part of empirical studies examining international trade flow has employed the gravity model (Khiyavi et al. 2013; Koksal 2016; Morland et al. 2020). It is called the gravity model due to the emphasis that is given to the distance between the production site and the consumption market. These regression models take the distance variable as a proxy for transport cost. Nevertheless, the considerable changes that globalization has brought to international trade have put the gravity model approach to critical rethinking (Abakumova and Primierova 2020). Globalization implies that the context in which countries interact should be almost equal to all countries. However, trade flows between countries are disturbed by economic, political, and environmental challenges (Zahonogo 2016; Bastiaens and Postnikov 2017). Russia is under sanctions from the EU since 2014 and is not buying EU citrus. A political tussle with Turkey in 2015 leads to a Russian embargo of Turkish fruit and vegetable import for almost two years. During the coronavirus pandemic, China had to suspend food exports to Russia. Apart from small areas cultivated by citrus in Russia, this country is not suitable for the production of this 
subtropical plant. Thus, Iran has an absolute advantage over Russia in citrus production and the productivity of its citrus orchards is comparable to other large suppliers of citrus to Russia from the northern hemisphere such as Turkey, Morocco, Egypt, Syria, and China (knoema.com). However, the particular context in which the Iranian export agents find themselves engaged creates serious obstacles for the realization of such trade. Foreign direct investment (FDI) has been lower than one percent of the GDP in the great part of the last 15 years (The World Bank 2021). The importance of FDI arises due to better information of multinational companies about export markets compared to local firms (Kutan and Vukšić, 2007). However, other direct and indirect effects of FDI on the elements that influence the economy are debated and it highly depends on the characteristics of the country's economy (Hall et al. 2010). The Iranian Rial has been depreciated more than ten times against the US dollar in the last decade. Exchange rate fluctuation has been evaluated to have different impacts on the volume of export. Arize et al. (2000) and Doğanlar (2002) have concluded that unpredictability of the exchange rate reduces the level of trade in developing and low-income countries. This is while Serenis and Tsounis (2014) have found positive effects of exchange rate fluctuations on export. Eventually, Hall et al. (2010) found no significant impact between these two variables. Decreasing the value of the national currency is most probable to engender an inflation rate in the country. A review of consumer price index of Iranian urban areas in the past 35 years shows that the inflation rate has been recorded over 35 percent in three major years including 1993, 2011, and 2020 (Central Bank of Iran, 2021). This is while the average inflation rate is about 20 percent. All of these three mentioned years are successive years in which the Iranian currency declined considerably (almost a threefold reduction). Nevertheless, like the impact of the exchange rate on the export, there is no clear relation identified in the economic studies between the inflation rate and the volume of foreign trade. Oil and gas sectors dominate both the Iranian and Russian economies. Sharp changes in oil prices influence the budgets of both countries. A critical reduction of oil prices would probably prevent the bilateral trade agreements due to low budgets which have not been predicted. In case of a sharp increase in the oil prices, the revenues of the two countries would rise, but they would not be able to use these sudden high revenues to improve the trade volume right away. Hence, an oil price shock, whether an increase or decrease, influences adversely the bilateral trade of these two exporting oil countries (Rasoulinezhad 2016). Iranian financial institutes and banks were excluded from the Society for Worldwide Interbank Financial Telecommunication (SWIFT) through the new set of financial sanctions against the country in 2012 (Belobrov et al. 2014) (Rasoulinezhad 2016). It is obvious that Iran's disconnection from the SWIFT system had created difficulties for financial transactions. To continue their trade, agents have inclined toward alternative means of transaction such as establishing a branch of a company at the destination market. Iranian export support programs have taken into consideration these limitations and tried to remove these obstacles. These programs include offering bank loans with relatively lower interest rates, subsidizing means of transport, facilitating the bilateral exchange of agents, support for establishing branches in destination markets and holding educational courses in marketing (Iranian Governmental Council 2020). Emphasizing the attributes of a healthy and highquality product is a marketing strategy that can guarantee receiving high prices for the exported product. Besides the voluntary quality attributes there are obligatory sanitary and phytosanitary standards to be respected at the customs (Henson and Loader 2001). The trade of agricultural products requires licenses certifying their nonnegative effect on the society and environment of the destination country (Rosselkhoznadzor). Sanitary and phytosanitary measures defined by the Russian plant protection organization as requirements for the import of citrus fruits set the minimum quality standards which the export countries need to respect to reach the Russian citrus market (Mutamiswa et al. 2020).

\subsection{The importance of the current study}

As described, the development of the economic situation is the most major concern of any government, and it is not an exception for Iran. One of the supreme ways to earn money for any society is to export. Most of Iran's exports are oil and its derivatives. Oil is a non-renewable resource, and its exports and sales have become very low and difficult due to the sanctions imposed. All these problems have forced the government to export other non-oil products. Given Iran's suitable conditions in the agricultural sector and its good position in this field in the world, the government has planned to increase the export of this product. To achieve this goal, appropriate approaches should be adopted and applying the appropriate approach requires identifying existing potentials and obstacles. Therefore, to consider the importance and necessity of the subject, in this research, we analyzed and studied the problem and provided useful solutions. In addition, in this investigation, widely used methods such as the Delphi and the fuzzy DEMATEL methods have been used for the first time in this domain. 


\section{Problem description}

Foreign trade is one of the important components in economic development and a source for the FEEs to invest in new technology and increase the production capacity of the country. The largest share of Iran's economic valuation process relies more on oil and petroleum products. In recent years, the existence of price fluctuations in the oil market, the FEEs of the country have faced many changes and have had a significant impact on the country's economy. On the other hand, oil and its derivatives are nonrenewable resources. All of these necessitate that the government substitutes non-oil exports for oil and its products. One of the important and significant production sectors for foreign trade is the agricultural sector. Paying attention to the agricultural sector not only leads to food security and national self-sufficiency but also can become a huge and fundamental source of exports and FEEs. Therefore, to strengthen the export of agricultural products and economic development through it, the government must adopt correct and supportive policies and identify the factors affecting the export of this type of product and remove the existing obstacles.

Mazandaran province is known as one of the leading provinces in the agricultural sector in Iran and its main agricultural products are rice and citrus. Nowadays, most of the citrus in Mazandaran province is exported to Russia. But there are still some problems and barriers to further export development to this country. Therefore, to identify existing barriers and limitations, provide useful and efficient solutions to strengthen exports to the government and export stakeholders in the province, the current study investigates and analyzes the variables affecting the citrus exports of the province to Russia.

\subsection{Case study}

Mazandaran province is one of the 31 provinces of Iran, which is located on the southern coast of the Caspian Sea. The area of the province is about 24,000 square kilometers. Having a temperate climate, sufficient rainfall, and the existence of fertile lands has made this province the main hub for the production of various agricultural products in Iran. Also, the main economy of Mazandaran province is based on agriculture. Besides, according to the statistics of the Ministry of Agriculture Jihad, this province has the first place in citrus production in the country. Various types of citrus are produced in the province, but those that include a larger share of production are Orange, Bitter orange, Tangerine, Sweet lemon, Sour Lemon, and Grapefruit. The major and large share (approximately \%85) of citrus production in Mazandaran province is for orange. Figure 1 represents the geographical location of Mazandaran province. The shape and appearance of each type of the mentioned citrus produced in the province are shown in Fig. 2.

\section{Methodology}

The methodology process, shown in Fig. 3, consists of three main parts. First, the variables affecting citrus exports are extracted and identified by examining the literature review. Then, the variables which have the greatest impact on citrus exports regarding the case study are selected using the Delphi method. Finally, the weight of each variable is calculated, and also, they are ranked by applying the fuzzy DEMATEL method.

\subsection{Extracted variables}

As mentioned before, the main goal of this study is to find and then rank the variables that have the greatest impact on citrus exports from Mazandaran province to Russia. Therefore, in this section, first, all the variables affecting citrus exports (not just related to the case study) are extracted from the literature review, which can be seen in Table 1. According to the table, 16 variables are identified and extracted and the related reference to each variable is also provided in the table. Besides, a brief explanation about each variable is presented in Table 1.

\subsection{Delphi method}

The complexity of new issues in the field of technology and information systems has led to the expansion of the use of consensus methods that one of them is the Delphi method. The Delphi technique is one of the most widely used methods in group decision making (Shah et al. 2019). The Delphi method as a qualitative method constructs the process of group communication in a way that provides the basis for the interaction of experts as a whole, to solve the problem (Singh and Sarkar 2020). In this method, a group of experts is selected and all the implementations and results are based on their opinions. The main purpose of the Delphi technique is to reach a consensus on a specific topic without that the experts be aware of other experts' opinions (Miller et al. 2020). There is no specific number of experts in the Delphi method, but most research recommends at least 10 experts (Robbins et al. 1993) (Murry Jr and Hammons 1995) (Okoli and Pawlowski 2004). Therefore, in this research, 15 experts' viewpoints are used to implement the Delphi method.

Figure 4 represents the steps of the Delphi method which contains three main processes including the 


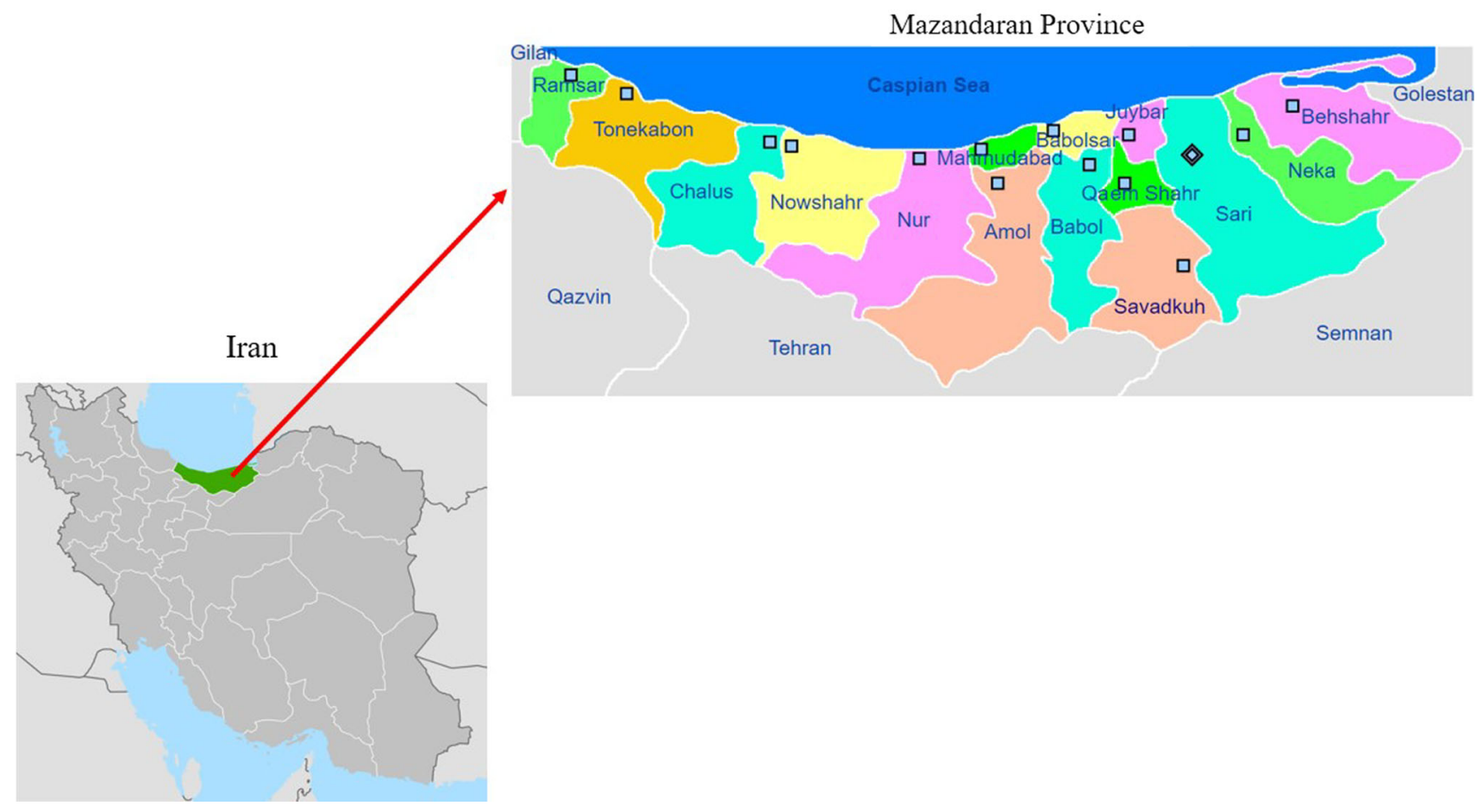

Fig. 1 The geographical map of the study region

Fig. 2 Different types of citruses produced in Mazandaran province

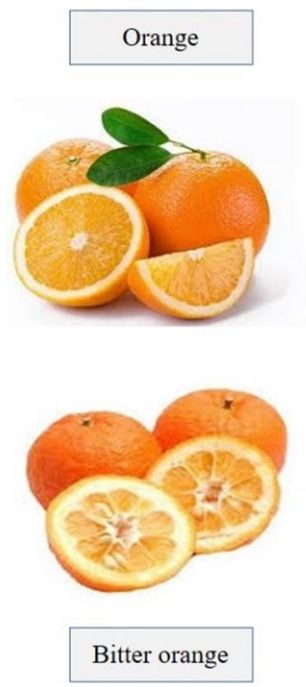

selection of expert committee' members, the implementation of rounds, and the final conclusion and report. A noteworthy point about the method is that there is no agreement on the number of rounds this technique should be implemented (Sung 2001). However, in most studies 2 to 3 rounds are recommended (Linstone and Turoff 1975) (Gordon 1994) (Okoli and Pawlowski 2004). Therefore, in this method, due to the low number of identified factors two rounds are considered.
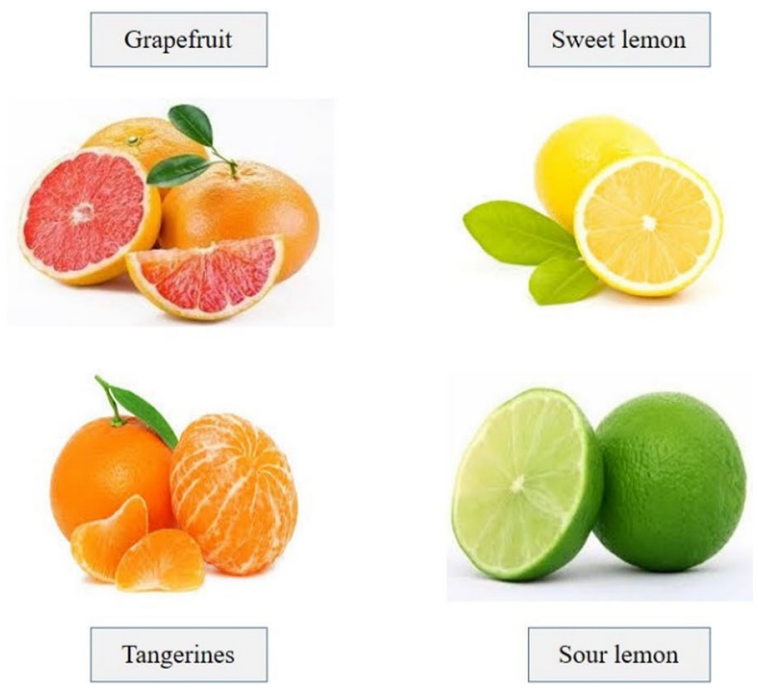

In this method, the Likert spectrum is used to receive the experts' opinions in each round. This spectrum has different types where one of them is the two-point spectrum. The two-point spectrum includes Yes or No that Yes means agreement, and No means that the expert disagrees with the issue (Lewis 1993). Another important point about this method is that if more than $67 \%$ of experts agree on an issue, it indicates a collective agreement on that issue (Alexandrov et al. 1996). 


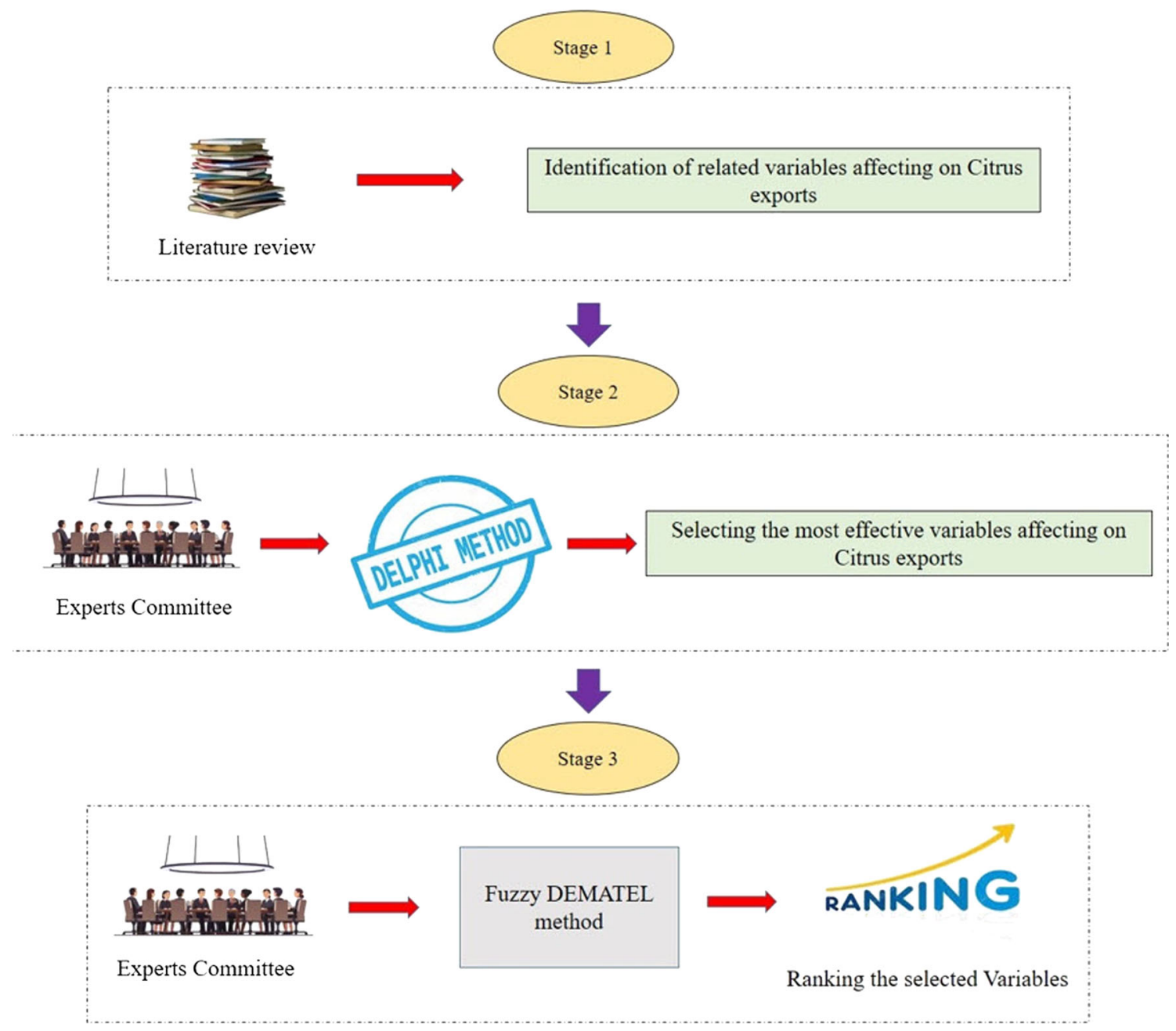

Fig. 3 The framework of the methodology

The Delphi method is usually used in combination with one of the multi-criteria decision-making (MCDM) methods in studies (Kumar et al. 2017). In this way, first by using this method, the most effective variables are identified and then one of the MCDM methods such as AHP, ANP, or DEMATEL is applied to obtain the weight of each variable. In this study, after identifying the factors that have the greatest impact on citrus exports from Mazandaran province to Russia, the fuzzy DEMATEL method is used to calculate the weight of each factor and then prioritize them.

\subsection{Fuzzy DEMATEL}

The name of the DEMATEL technique is derived from the phrase "Decision Making Trial and Evaluation" and is a common method of MCDM. It has been developed to study and solve complex and intertwined problems in the universe (Tzeng et al. 2010). This technique is based on pairwise comparisons and graph theory. In other words, this technique determines their impact and importance as a numerical score by examining the interrelationships between factors (Han and Deng 2018). In addition to transforming cause-and-effect relationships into a structural-visual model, it is also able to identify the internal dependencies between factors and make them understandable (Feng and Ma 2020). Also, the method is done based on the opinion of experts to make the pairwise comparison between the factors (Hasheminezhad et al. 2021). Obviously, estimating the opinion of experts with accurate numerical values under uncertainty is very difficult. Fuzzy logic is one of the tools that can be employed to address this difficulty (Suo et al. 2012). Utilizing this tool leads to reach a method so-called Fuzzy DEMATEL in the literature (Hosseini and Paydar 2021b). Figure 5 shows the indispensable steps of the fuzzy DEMATEL method. Also, more details about the method are found in the research of Li et al., (2020). 
Table1 Extracted factors based on the literature review

\begin{tabular}{|c|c|c|c|}
\hline Sign & Variables & References & A brief explanation \\
\hline V1 & $\begin{array}{l}\text { Productivity of } \\
\text { citrus orchards }\end{array}$ & $\begin{array}{l}\text { Ebadi and Ebadi (2015), Najafi } \\
\text { Alamdarlo (2016) }\end{array}$ & The efficiency of production factors (land, labor, capital) \\
\hline $\mathrm{V} 2$ & $\begin{array}{l}\text { Gross Domestic } \\
\text { Product (GDP) }\end{array}$ & $\begin{array}{l}\text { Abakumova and Primierova } \\
\text { (2020) }\end{array}$ & GDP of exporting and importing country \\
\hline $\mathrm{V} 3$ & $\begin{array}{l}\text { KOF globalization } \\
\text { index }\end{array}$ & Gygli et al. (2019) & A measure of economic, social, and political dimensions of globalization \\
\hline V4 & $\begin{array}{l}\text { Exchange rate } \\
\text { fluctuation }\end{array}$ & Serenis and Tsounis (2014) & The value variation of a currency regarding another \\
\hline V5 & $\begin{array}{l}\text { Economic openness } \\
\text { index }\end{array}$ & Najafi Alamdarlo (2016) & $\begin{array}{l}\text { Agricultural Export (US \$) + Agricultural Import (US \$) } \\
\text { Agricultural value added (US \$) }\end{array}$ \\
\hline V6 & $\begin{array}{l}\text { Agricultural value } \\
\text { added }\end{array}$ & $\begin{array}{l}\text { Ebadi and Ebadi (2015; Najafi } \\
\text { Alamdarlo (2016) }\end{array}$ & Agricultural product value-cost of agricultural inputs \\
\hline V7 & $\begin{array}{l}\text { Foreign direct } \\
\text { investment }\end{array}$ & Najafi Alamdarlo (2016) & $\begin{array}{l}\text { Financial and managerial involvement of multinational companies in the } \\
\text { production and marketing of a product }\end{array}$ \\
\hline V8 & Financial sanction & Rasoulinezhad (2016) & $\begin{array}{l}\text { Sanctions on the Iranian banks and the Central bank of Iran, being excluded } \\
\text { from the SWIFT system }\end{array}$ \\
\hline V9 & $\begin{array}{l}\text { Sharp changes in oil } \\
\text { price }\end{array}$ & (Rasoulinezhad 2016) & An oil price shock, whether an increase or decrease \\
\hline V10 & $\begin{array}{l}\text { Export supporting } \\
\text { policies }\end{array}$ & Balli et al. (2011), Moon (2015) & $\begin{array}{l}\text { Financial and infrastructural facilities provided by the government for the } \\
\text { foreign trade }\end{array}$ \\
\hline V11 & $\begin{array}{l}\text { Number of } \\
\text { expatriates }\end{array}$ & Balli et al. (2011) & Number of expatriates in foreign markets \\
\hline V12 & $\begin{array}{l}\text { Sanitary and } \\
\text { phytosanitary } \\
\text { measures }\end{array}$ & $\begin{array}{l}\text { Henson and Loader (2001), } \\
\text { Crivelli and Gröschl (2016) }\end{array}$ & $\begin{array}{l}\text { Risk-reducing measures imposed by importing country with the objective of } \\
\text { protection of food safety, plant and animal health, and the natural } \\
\text { environment }\end{array}$ \\
\hline V13 & Marketing & $\begin{array}{l}\text { Hatab (2016), Spreen et al. } \\
\text { (2020) }\end{array}$ & Activities targeting higher sales at the destination market \\
\hline V14 & Inflation rate & Ebadi and Ebadi (2015) & The percentage increase of prices in a year \\
\hline V15 & Competitiveness & $\begin{array}{l}\text { Dubravska and Sira (2015), } \\
\text { Ebadi and Ebadi (2015) }\end{array}$ & a measure of the relative ability of different countries to provide the product \\
\hline V16 & Distance & $\begin{array}{l}\text { Abakumova and Primierova } \\
\text { (2020) Morland et al. (2020) }\end{array}$ & Land road access, Tehran-Moscow: $3042 \mathrm{~km}$ \\
\hline
\end{tabular}

\section{Implementation and findings}

\subsection{Delphi}

The first and most important step to implement the Delphi method is forming a committee of experts. In this study, a group of 15 experts including (1) two experts from Mazandaran Chamber Of Commerce Industries Mines and Agriculture, (2) three experts from Industry, Mine and Trade Organization of Mazandaran, (3) one expert from Agricultural Research, Education and Extension Organization of Mazandaran, (4) three experts from Romak Food Logistics center, (5) three experts from Agriculture Organization of Mazandaran, and (6) three professors of Sari Agricultural Sciences and Natural Resources University is formed. Therefore, with the help of these experts, the
Delphi method is performed. The results obtained from implementing the method are presented in Table 2 . According to this table, this method is performed in two rounds. In the first round, experts reach consensus on 12 variables. In other words, they believed that variables including V2, V3, V5, and V16 do not have a significant effect on citrus exports regarding the case study, so these variables are eliminated. In the second round, the remaining 12 variables are evaluated by experts and based on their opinions, the variables including V6 and V11 are eliminated. To put it another way, variables V1, V4, V7, V8, V9, V10, V12, V13, V14, and V15 are selected as the variables which have the major impact on citrus exports from Mazandaran province to Russia. 
Fig. 4 Steps of the Delphi method

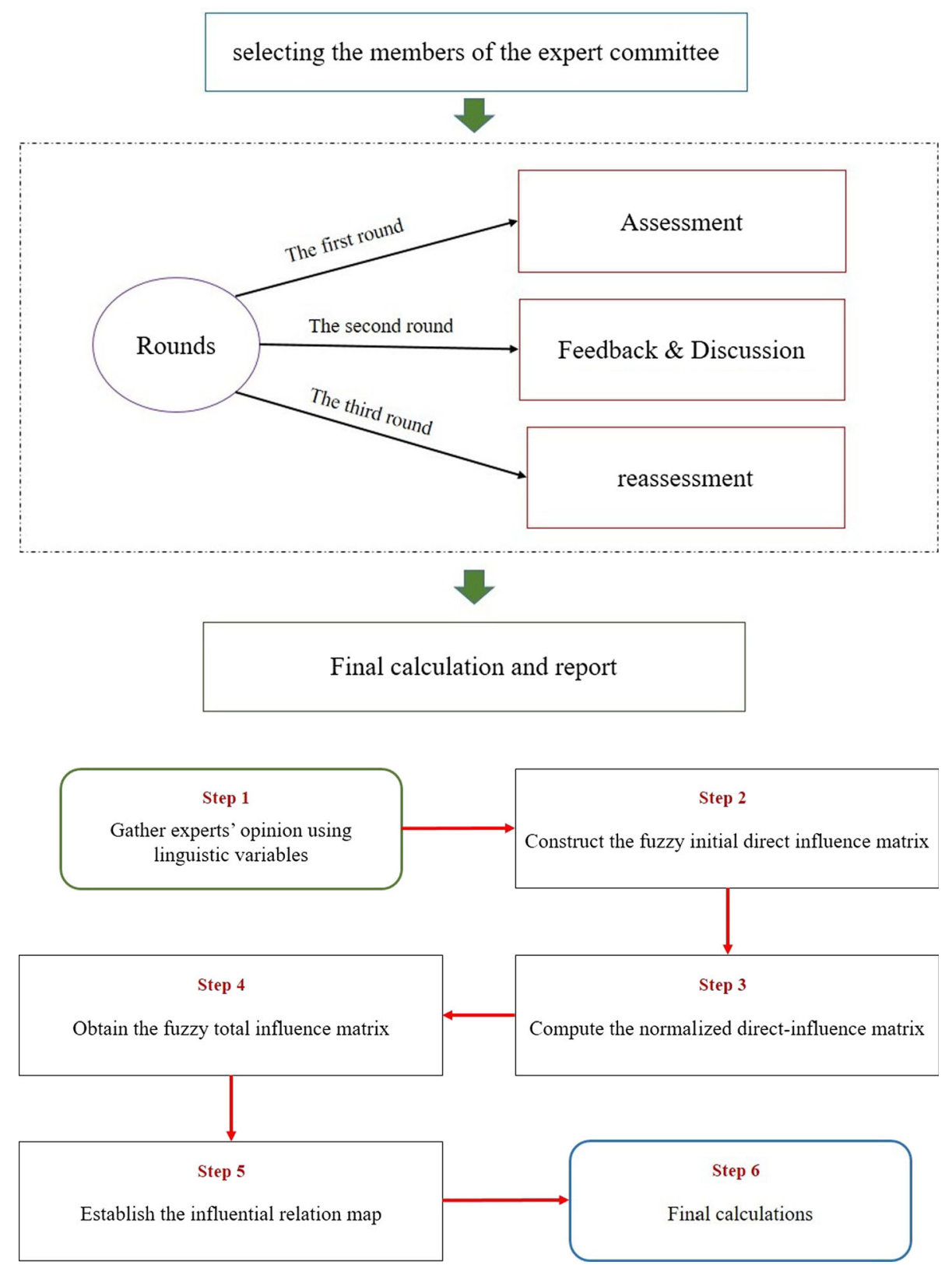

Fig. 5 Steps of the Fuzzy DEMATEL
Table 2 The implementation results of the Delphi method

\begin{tabular}{lllll}
\hline Round & Questions & Agree & Disagree \\
\cline { 3 - 4 } & & Number & Number & Variable \\
\hline Round 1 & 16 & 12 & 4 & V2, V3, V5, and V16 \\
Round 2 & 12 & 10 & 2 & V6 and V11 \\
\hline
\end{tabular}

\subsection{Fuzzy DEMATEL}

To prioritize the selected variables based on the Delphi method, the fuzzy DEMATEL method is applied. The initial data required for the implementation of the method are collected based on the viewpoints of the experts who are members of the expert committee formed for the Delphi method. In this regard, the biggest computational complexity of the proposed method was their opinions which were expressed in the form of verbal expressions such as very low and good and these verbal terms should convert into equivalent numerical values to continue the implementation of the DEMATEL method. To solve this great problem, the fuzzy logic was used and combined with the DEMATEL method that named the fuzzy DEMATEL method. The fuzzy linguistic variable (FLV) presented in Table 3 is used to receive the experts' opinions, and then, these verbal terms are converted into equivalent numerical 
Table 3 The FLV for evaluation ( $\mathrm{Li}$ et al. 2020)

\begin{tabular}{lll}
\hline Linguistic terms & Abbreviations & TFN \\
\hline No influence & NI & $(0,0,0.25)$ \\
Very low influence & VL & $(0,0.25,0.5)$ \\
Low influence & L & $(0.25,0.5,0.75)$ \\
High influence & HI & $(0.5,0.75,1)$ \\
Very high influence & VH & $(0.75,1,1)$
\end{tabular}

values. In this study, we considered the triangular fuzzy number (TFN). Suppose that $\tilde{F}$ is a TFN, so it is shown as $\tilde{F}=\left(F^{l}, F^{m}, F^{u}\right)$. Finally, the average of numerical values is calculated and shown in Table 4 as the fuzzy initial direct influence (FIDI) matrix. Tables 5 and 6 indicate the fuzzy normalized direct influence (FNDI) matrix and the fuzzy total influence (FTI) matrix, respectively. The final results and calculation obtained from the fuzzy DEMATEL method are provided in Table 7 . The weight of each variable is gained based on Eq. 1(Baykasoğlu et al. 2013). In Eq. 1, $\quad\left(\tilde{D}_{i}+\tilde{R}_{i}\right)^{\text {def }}$ and $\left(\tilde{D}_{i}-\tilde{R}_{i}\right)^{\text {def }}$ represent the defuzzification value of $\tilde{D}_{i}+\tilde{R}_{i}$ and $\tilde{D}_{i}-\tilde{R}_{i}$, respectively. The graded mean integration representation (GMIR) method is used to calculate these values. The formula of GMIR method is presented in Eq. 2 (Zhao and Guo 2015).

$$
\begin{aligned}
& W_{i}=\frac{\left[\left(\left(\tilde{D}_{i}+\tilde{R}_{i}\right)^{\text {def }}\right)^{2}+\left(\left(\tilde{D}_{i}-\tilde{R}_{i}\right)^{\text {def }}\right)^{2}\right]^{1 / 2}}{\sum_{i=1}^{n}\left[\left(\left(\tilde{D}_{i}+\tilde{R}_{i}\right)^{\text {def }}\right)^{2}+\left(\left(\tilde{D}_{i}-\tilde{R_{i}}\right)^{\operatorname{def}}\right)^{2}\right]^{1 / 2}} \\
& \tilde{F}^{\text {def }}=\frac{F^{l}+4 \times F^{m}+F^{u}}{6}
\end{aligned}
$$

Based on the weights obtained for each variable, the final prioritization in terms of influencing citrus exports from Mazandaran province to Russia is according to Fig. 6. Based on Fig. 6, V4 "Exchange rate fluctuation" and V13 "Marketing" have the highest and lowest impact on citrus exports regarding the case study, respectively.

\subsection{Discussion}

The goal of applying the Delphi method before ranking the variables using fuzzy DEMATEL was to filter the most relative ones. Besides analyzing the quantitative data, questions were also posed to identify the argument behind their decision. The main argument behind the exclusion of those variables in the process of Delphi analysis was the convergence between two or more of them. The GDP was excluded for the sake of "agricultural added value" which is itself a component of GDP. At another stage, agricultural added value was excluded for the productivity of citrus orchards. This tendency of keeping specifically related variables, in case of availability, dominated the arguments of respondents. The GDPs of the two countries are the main components of gravity regression models, and their importance in international trade is not ignorable. Nevertheless, the intention of this study was not to be comprehensive of all variables that affect the trade flow between the two countries but to clarify the effect of certain variables that their impacts were ambiguous. This is also the reason why distance has been omitted from the ranking. There is no doubt on the impact of distance on the transport costs. However, as the study is focused on two countries (the distance between Tehran and Moscow is about three thousand kilometers) and transport technology is not expected to improve in short run, the transport cost is assumed fixed.

The argument which applied for the exclusion of "economic openness index" and "KOF globalization index" was based on their composite nature. As these two indicators are composed of several other indicators, some even included in the study, the experts have preferred to keep single criteria variables instead. Eventually what we referred to by "Number of expatriates" was the probability of undertaking marketing activities by those Iranians already settled in Russia. The marketing variable was considered comprehensive of that variable. In total, ten variables have been extracted from the initial list of variables and the ranking of them has been assessed using the fuzzy DEMATEL method. The most astonishing point in the results is the indication of the exchange rate as the most important variable and the inflation rate as one before the last effective variable on the level of citrus export from Iran to Russia. The depreciation of the national currency against the foreign currency is a common export promotion policy that provides the exporting agents with more amount of domestic currency for the same quantity of exported goods. However, its contribution to export growth is doubtful. It may be employed by governments to stimulate foreign trade in short run. However, in long term, if the mutual trade continues for a relatively long time, the domestic prices will reach an equilibrium with the international prices. This fact puts into question the big difference between the rankings of exchange and the inflation rate. In reality, it denies the convergence of these two variables in Iran. The parallel augmentation of domestic prices would probably reduce the export quantity as selling locally would be as much attractive as selling abroad.

To present a clearer picture of the discussion, the variables are categorized into two main groups based on stages of trade and are shown in Fig. 7. The groups are including "Structural variables" and "at border and beyond 


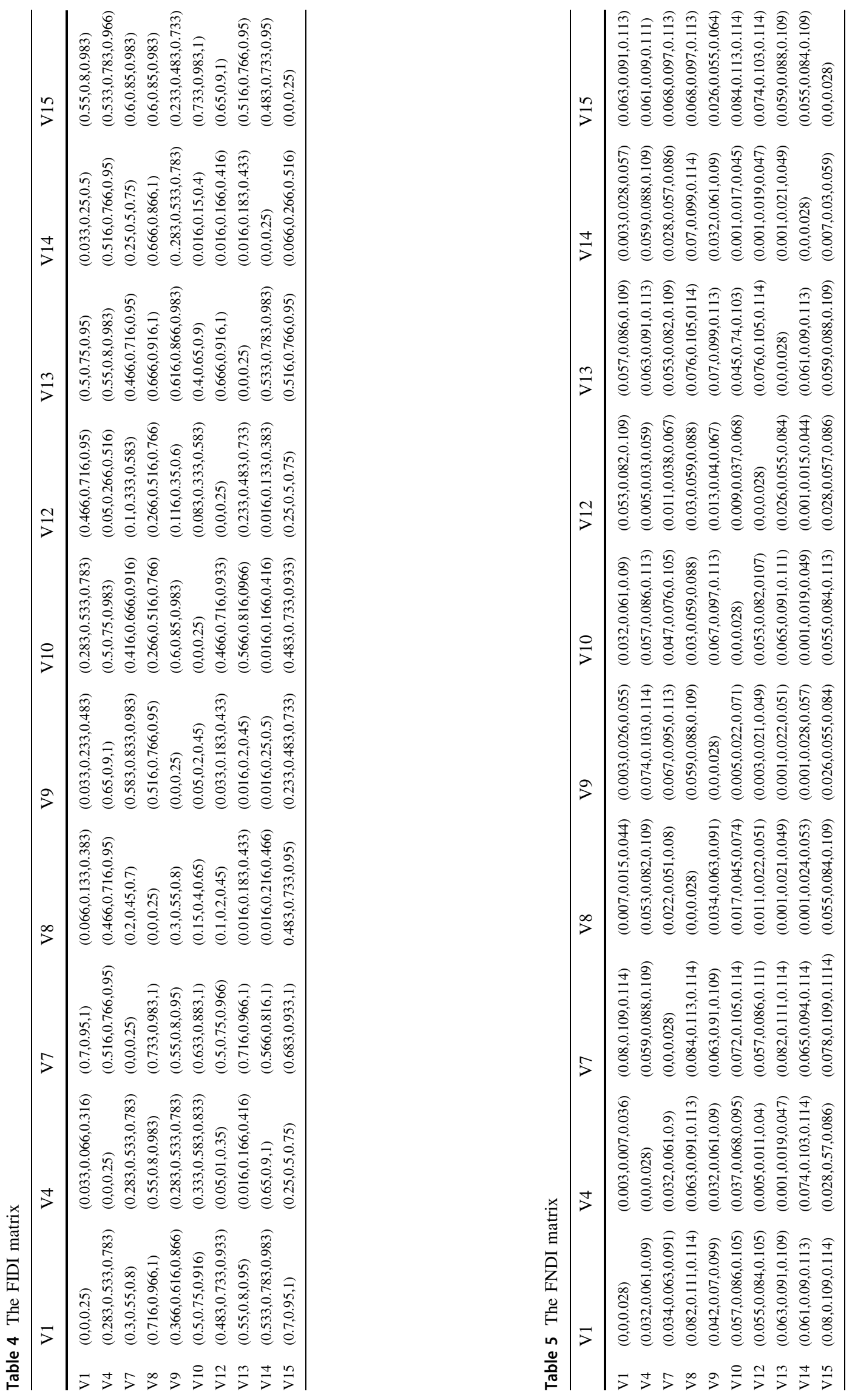




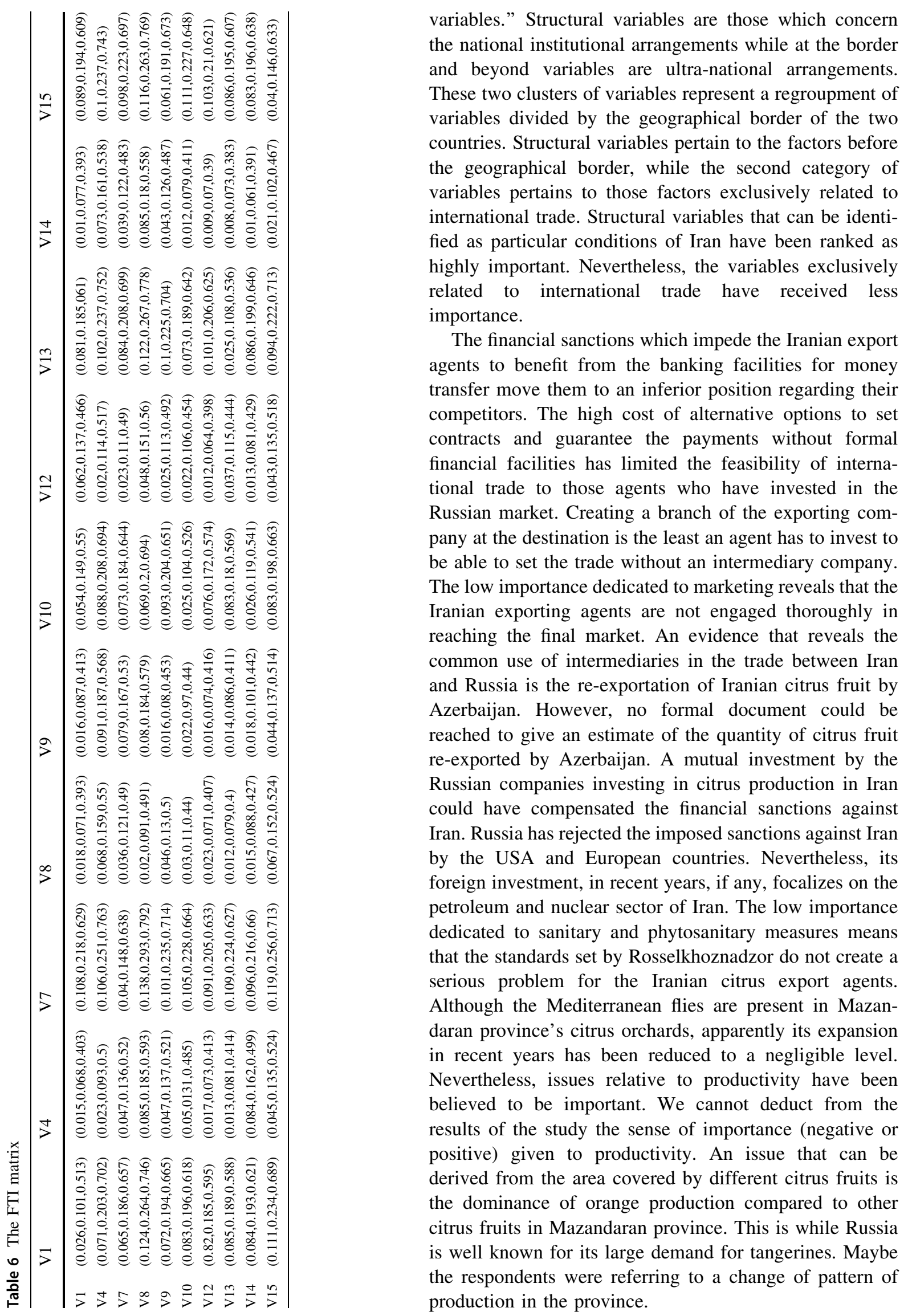

variables." Structural variables are those which concern the national institutional arrangements while at the border and beyond variables are ultra-national arrangements. These two clusters of variables represent a regroupment of variables divided by the geographical border of the two countries. Structural variables pertain to the factors before the geographical border, while the second category of variables pertains to those factors exclusively related to international trade. Structural variables that can be identified as particular conditions of Iran have been ranked as highly important. Nevertheless, the variables exclusively related to international trade have received less importance.

The financial sanctions which impede the Iranian export agents to benefit from the banking facilities for money ransfer move them to an inferior position regarding their contracts financial facilities has limited the feasibility of internapany at the destination is the least an agent has to invest to e able to set the trade without an intermediary company. reaching the final market. An evidence that reveals the reached to give an estimate of the quantity of citrus fruit A mutual investment by the in Iran inst Iran the USA and European countries. Nevertheless, its inn investment, in recent years, if any, focalizes on the etroleum and nuclear sector of Iran. The low importance means create a Alous problem for the Iranian citrus export agents. Although the Mediterranean flies are present in Mazanaran province's citrus orchards, apparently its expansion recent years has been reduced to a negligible level. evertheless, issues relative to productivity have been elieved to be important. We cannot deduct from the results of the study the sense of importance (negative or positive) given to productivity. An issue that can be derived from the area covered by different citrus fruits is the dominance of orange production compared to other citrus fruits in Mazandaran province. This is while Russia is well known for its large demand for tangerines. Maybe production in the province. 
Table7 Final calculations

\begin{tabular}{llllll}
\hline Variable & $\tilde{D}$ & $\tilde{R}$ & $(\tilde{D}+\tilde{R})^{\text {def }}$ & $(\tilde{D}-\tilde{R})^{\text {def }}$ & W \\
\hline V1 & 1.771 & 2.500 & 4.271 & -0.728 & 0.118 \\
V4 & 2.417 & 2.342 & 4.759 & 0.075 & 0.130 \\
V7 & 2.146 & 2.077 & 4.223 & 0.069 & 0.115 \\
V8 & 2.632 & 1.833 & 4.465 & 0.800 & 0.124 \\
V9 & 2.173 & 1.511 & 3.684 & 0.661 & 0.102 \\
V10 & 1.960 & 1.259 & 3.219 & 0.701 & 0.090 \\
V12 & 1.839 & 1.011 & 2.850 & 0.827 & 0.081 \\
V13 & 1.800 & 0.775 & 2.575 & 1.025 & 0.076 \\
V14 & 1.918 & 0.537 & 2.454 & 1.381 & 0.077 \\
V15 & 2.258 & 0.290 & 2.548 & 1.968 & 0.088 \\
\hline & & & & &
\end{tabular}

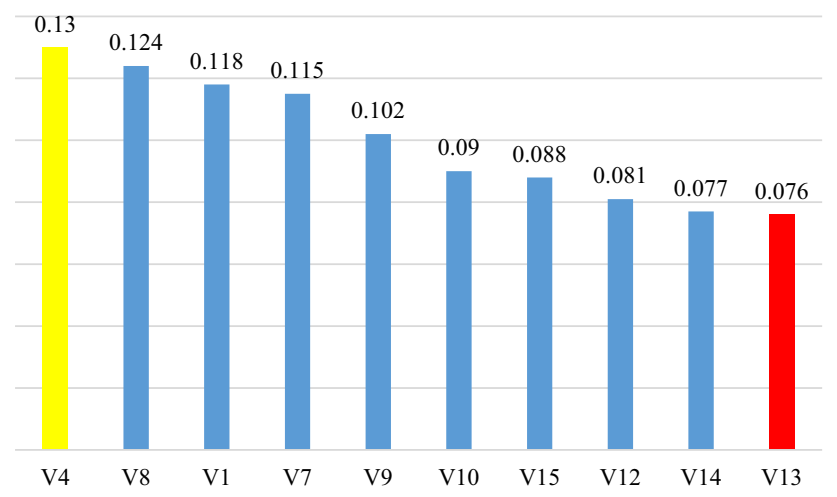

Fig. 6 Final ranking

\section{Conclusion}

Iran has focused on exporting agricultural products, especially citrus, instead of oil and oil products to improve its economic situation. Therefore, the government is looking for a suitable strategy to develop the export of this type of product. Mazandaran province is one of the main hubs of citrus production in the country and a considerable quantity of the produced citrus in this province is exported to Russia. Due to the good political relations between Iran and Russia, it is possible to export more to this country and this action is not possible except by examining the variables affecting exports and removing existing barriers. Therefore, in this paper, we have studied the variables affecting the citrus export from the province to Russia. First, the variables affecting exports (not only citrus exports) are identified from the literature review. Then, the variables related to citrus exports regarding the case are identified using the Delphi method. In other words, first, 16 variables affecting exports in each field are identified and then based on the Delphi method, 10 of the most related variables affecting citrus exports are identified and selected. Finally, the 10 selected variables are prioritized by applying the fuzzy DEMATEL method. The importance that has been given to the national economic structure implies that improvements in features of the national economy such as stability of exchange rate and offering banking facilities would lead smoothly to higher levels of citrus export to Russia. The depreciation of national currency may boost an export-oriented movement among the export agents by receiving more amount of currency per

Fig. 7 Categorizing the variables into two main groups

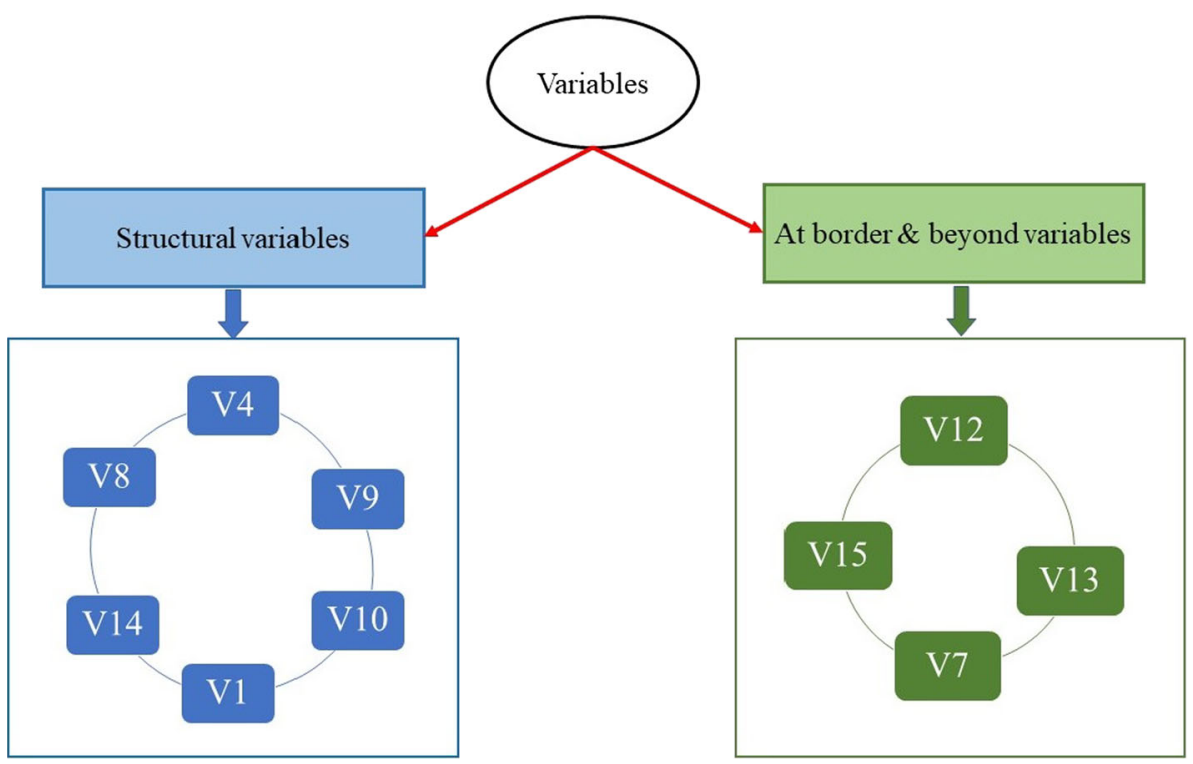


exported unit of good. However, in long term, the citrus cost of production and the benefits from exports would reach an equilibrium that reduces the comparative advantage of the country compared to other years. The influence that financial sanctions have on the access of agents to international banking facilities raises transaction costs. A more detailed study on the impact of this cost on trade is recommended. We may propose new institutional economics as an approach to the analysis of these transaction costs. Transaction costs analysis covers a vast variety of costs including contract failures and guarantees. A longlasting trade relation between partners is expected to take place after trust building and a robust supply chain. Finally, one should bear in mind that the results of this study indicate the importance and the weight of the studied variables in comparison with each other in the context of the Iranian political and economic environment.

Author contributions SMH, YS, and MMP contributed to the design and implementation of the research, to the analysis of the results and the writing of the manuscript.

Funding Not applicable.

\section{Declarations}

Conflict of interest All three authors declare that they have no conflict of interest.

Ethical approval This study does not involve any human participants or animals' studies performed by any of the authors.

Informed consent Not applicable.

\section{References}

Abakumova J, Primierova O (2020) Globalization and export flows between Eurasian Economic Union countries: a gravity model approach. SHS Web of Conferences. EDP Sciences, pp 06001

Alexandrov AV, Pullicino PM, Meslin EM, Norris JW (1996) Agreement on disease-specific criteria for do-not-resuscitate orders in acute stroke. Stroke 27:232-237

Arize AC, Osang T, Slottje DJ (2000) Exchange-rate volatility and foreign trade: evidence from thirteen LDC's. J Bus Econ Stat 18:10-17

Balli F, Louis RJ, Osman M (2011) The patterns of cross-border portfolio investments in the GCC region: do institutional quality and the number of expatriates play a role? $\mathrm{J}$ Econ Financ 35:434-455

Bastiaens I, Postnikov E (2017) Greening up: the effects of environmental standards in EU and US trade agreements. Environ Polit 26:847-869

Baykasoğlu A, Kaplanoğlu V, Durmuşoğlu ZD, Şahin C (2013) Integrating fuzzy DEMATEL and fuzzy hierarchical TOPSIS methods for truck selection. Expert Syst Appl 40:899-907
Belobrov Y, Volodin A, Demidenko S, Kozyrev N, Lankin E, Novikov V, Sazhin V, Yurtaev V (2014) Modern RussianIranian relations: challenges and opportunities

Chen H (2009) A literature review on the relationship between foreign trade and economic growth. Int J Econ Financ 1:127-130

Chiadamrong N, Kawtummachai R (2008) A methodology to support decision-making on sugar distribution for export channel: a case study of Thai sugar industry. Comput Electron Agric 64:248-261

Crivelli P, Gröschl J (2016) The impact of sanitary and phytosanitary measures on market entry and trade flows. World Econ 39:444-473

Doğanlar M (2002) Estimating the impact of exchange rate volatility on exports: evidence from Asian countries. Appl Econ Lett 9:859-863

Dubravska M, Sira E (2015) The analysis of the factors influencing the international trade of the slovak republic. Proc Econ Financ 23:1210-1216

Ebadi A, Ebadi A (2015) How the export volume is affected by determinant factors in a developing country. Res World Econ 6:143-150

Esfahani HS, Mohaddes K, Pesaran MH (2013) Oil exports and the Iranian economy. Q Rev Econ Financ 53:221-237

Esnaashari H, Karbasi A, Mosannen Mozafari M (2010) Foreign trade and input efficiency relationship in the agricultural sector of Iran. Agric Econ Res 2:105-114

Feng C, Ma R (2020) Identification of the factors that influence service innovation in manufacturing enterprises by using the fuzzy DEMATEL method. J Clean Prod 253:120002

Genç S, Akay D, Boran FE, Yager RR (2020) Linguistic summarization of fuzzy social and economic networks: an application on the international trade network. Soft Comput 24:1511-1527

Goldstein M, Khan MS (1985) Income and price effects in foreign trade. Handb Int Econ 2:1041-1105

Gordon TJ (1994) The Delphi method. Futures Res Methodol 2:1-30

Gygli S, Haelg F, Potrafke N, Sturm J-E (2019) The KOF globalisation index-revisited. Rev Int Organ 14:543-574

Hall S, Hondroyiannis G, Swamy P, Tavlas G, Ulan M (2010) Exchange-rate volatility and export performance: do emerging market economies resemble industrial countries or other developing countries? Econ Model 27:1514-1521

Han Y, Deng Y (2018) An enhanced fuzzy evidential DEMATEL method with its application to identify critical success factors. Soft Comput 22:5073-5090

Hasheminezhad A, Hadadi F, Shirmohammadi H (2021) Investigation and prioritization of risk factors in the collision of two passenger trains based on fuzzy COPRAS and fuzzy DEMATEL methods. Soft Comput 25:4677-4697

Hatab AA (2016) Demand relationships in orange exports to Russia: a differential demand system approach focusing on Egypt. Agric Food Econ 4:1-16

Henson S, Loader R (2001) Barriers to agricultural exports from developing countries: the role of sanitary and phytosanitary requirements. World Dev 29:85-102

Hosseini SM, Paydar MM (2021a) Discount and advertisement in ecotourism supply chain. Asia Pac J Tour Res 26:668-684

Hosseini SM, Paydar MM (2021b) Examining and prioritizing the factors affecting tourist absorption for ecotourism centers utilizing MCDM tools. J. Optim. Indus. Eng. 45:4566

https://fsvps.gov.ru.

https://knoema.com.

Khiyavi PK, Moghaddasi R, Yazdani S (2013) Investigation of factors affecting the international trade of agricultural products in developing countries. Life Sci J 10:409-414 
Koksal O (2016) Determinants of Turkey's citrus exports: a gravity model approach. New Medit Mediterr J Econ Agric Environ Revue Méditerranéenne D'economie Agric Et Environ 15:37

Kumar A, Kaviani MA, Hafezalkotob A, Zavadskas EK (2017) Evaluating innovation capabilities of real estate firms: a combined fuzzy Delphi and DEMATEL approach. Int J Strateg Prop Manag 21:401-416

Kutan AM, Vukšić G (2007) Foreign direct investment and export performance: empirical evidence. Comp Econ Stud 49:430-445

Lee Y-S, Liu W-Y (2014) Forecasting value of agricultural imports using a novel two-stage hybrid model. Comput Electron Agric 104:71-83

Lewis JR (1993) Multipoint scales: mean and median differences and observed significance levels. Int J Hum Comput Interact 5:383-392

Li H, Wang W, Fan L, Li Q, Chen X (2020) A novel hybrid MCDM model for machine tool selection using fuzzy DEMATEL, entropy weighting and later defuzzification VIKOR. Appl Soft Comput 91:106207

Linstone HA, Turoff M (1975) The delphi method. Addison-Wesley Reading, MA

Miller KA, Collada B, Tolliver D, Audi Z, Cohen A, Michelson C, Newman LR (2020) Using the modified Delphi method to develop a tool to assess pediatric residents supervising on inpatient rounds. Acad Pediatr 20:89-96

Moon W (2015) Conceptualising multifunctional agriculture from a global perspective: implications for governing agricultural trade in the post-Doha Round era. Land Use Policy 49:252-263

Morland C, Schier F, Weimar H (2020) The structural gravity model and its implications on global forest product trade. Forests 11:178

Murry JR, John W, Hammons JO (1995) Delphi: a versatile methodology for conducting qualitative research. Rev High Educ 18:423-436

Mutamiswa R, Tarusikirwa V, Nyamukondiwa C, Chidawanyika F (2020) Fluctuating environments impact thermal tolerance in an invasive insect species Bactrocera dorsalis (Diptera: Tephritidae). J Appl Entomol 144:885-896

Najafi Alamdarlo H (2016) Spatial and temporal factors affecting agricultural trade in the European: union:(EU) and economic cooperation organization (ECO). J Agric Sci Technol 18:1721-1733

Nijssen EJ, Douglas SP (2004) Examining the animosity model in a country with a high level of foreign trade. Int J Res Mark 21:23-38

Okoli C, Pawlowski SD (2004) The Delphi method as a research tool: an example, design considerations and applications. Inform Manag 42:15-29
Rasoulinezhad, E. 2016. Investigation of sanctions and oil price effects on the Iran-Russia trade by using the gravity model. Вестник Санкт-Петербургского университета. Экономика

Robbins R, Mcmanus R, Mitchell R, Latter D, Moon M, Olinger G, Miller D (1993) Management of patients with intramural hematoma of the thoracic aorta. Circulation 88:1-10

Serenis D, Tsounis N (2014) Exchange rate volatility and aggregate exports: evidence from two small countries. Int Sch Res Notices

Shah S, Solangi Y, Ikram M (2019) Analysis of barriers to the adoption of cleaner energy technologies in Pakistan using Modified Delphi and fuzzy analytical hierarchy process. J Clean Prod 235:1037-1050

Singh PK, Sarkar P (2020) A framework based on fuzzy Delphi and DEMATEL for sustainable product development: a case of Indian automotive industry. J Clean Prod 246:118991

Spreen TH, Gao Z, Fernandes W Jr, Zansler ML (2020) Global economics and marketing of citrus products. Elsevier, The Genus Citrus

Sung W (2001) Application of Delphi method, a qualitative and quantitative analysis, to the healthcare management. J Healthc Manag 2:11-19

Suo W-L, Feng B, Fan Z-P (2012) Extension of the DEMATEL method in an uncertain linguistic environment. Soft Comput $16: 471-483$

Teimoury E, Nedaei H, Ansari S, SABBAGHI, M. (2013) A multiobjective analysis for import quota policy making in a perishable fruit and vegetable supply chain: a system dynamics approach. Comput Electron Agric 93:37-45

Temiz Dinç D, Gökmen A, Nakip M, Azari NM (2017) The impact of foreign trade issues on economic growth in some developing countries including Iran and Turkey. J Transnatl Manag 22:171-202

Tzeng G-H, Chen W-H, Yu R, Shih M-L (2010) Fuzzy decision maps: a generalization of the DEMATEL methods. Soft Comput 14:1141-1150

www.maj.ir.

Zahonogo P (2016) Trade and economic growth in developing countries: evidence from sub-Saharan Africa. J Afr Trade 3:41-56

Zhao H, Guo S (2015) External benefit evaluation of renewable energy power in China for sustainability. Sustainability 7:4783-4805

Publisher's Note Springer Nature remains neutral with regard to jurisdictional claims in published maps and institutional affiliations. 